\title{
Computational Program for Simulation of Mass and Heat Transfer of Cerrado Fruits
}

\author{
Sara P. Fernandes \\ Computer Science Department \\ Federal University of Tocantins
}

\author{
Glêndara Aparecida de \\ Souza Martins \\ Food Engineering Department \\ Federal University of Tocantins
}

\author{
Warley Gramacho da \\ Silva
}

Computer Science Department

Federal University of Tocantins

\begin{abstract}
This work proposes the development of software that has the objective of simulating the drying of cerrado fruits. The project was constructed through bibliographical surveys that pointed out several mathematical models that represent phenomena of heat and mass transfer between product and drying air. The developed program is dynamic and based on the Thompson model, but allows the use of the Page model, as well as the open parameterization of some equations such as the conversion reason, specific heat, among others. The software developed allows the simulation of heat transfer process, minimizing time and costs applied in practical experiments preliminary.
\end{abstract}

\section{General Terms}

Software Engineering, Transport Phenomenon

\section{Keywords}

Simulator, Modeling, Transport phenomenon. Fruits

\section{INTRODUCTION}

Currently, even though there is a diversity of fruits that are consumed fresh in Brazil, the demand for processed foods has increased considerably, since the fresh fruits generally present high humidity values, which makes difficult to store and transport them in relation. Another criterion to be considered is the fact that some fruits, such as the cerrado fruits, are seasonal and have a reduced harvesting period, thus requiring the processing to increase its conservation and availability throughout the year.

With the goal of minimizing the deterioration of foods, some conservation techniques were developed, among which drying is one of the most used since it consists of a process of heat and mass transfer that has the consequence of reducing the moisture content and minimizing biochemical reactions of degradation [1]. In addition to being one of the processes used to enable the preservation of the quality of food, the drying can be addressed, too, such as the operation that allows obtaining products of better quality, and also enable harvests early, minimize the impact of possible deteriorations that can occur in the field [2] and increase the useful life of fresh fruits $[3,4,5,6]$.

In general, the analysis of drying parameters, as a result of experimental tests, is performed by several authors through paid software $[7,8]$ or traditional statistical tests that allow estimates of models that possibly explain the relationship between the variables studied, considering experimental errors $[9,10,11]$.

In this sense, was developed a specific and free software to simulate the drying of cerrado fruits, minimizing costs and time spent on preliminary experiments of drying for the determination of the operating parameters.

\section{MATERIAL AND METHODS}

\subsection{Mathematical Model}

The mathematical model to be implemented was the Thompson model [12]. This model proposes the analysis of drying process from the conditions of drying air, air flow, fruit, layer thickness and water initial content in the product. The authors divided the continuous process of drying in several stages, simulating them through the consecutive calculations of transfers that occur during small increments of time. In Fig 1, is shown schematically one of these processes. During a time interval, Dt, a quantity of water, DX, is evaporated and transported by the air, which increases its water ratio, $\mathrm{RX}$, to $\mathrm{RX}+\mathrm{DRX}$. During drying, the air temperature decreases from a DT value proportional to temperature increase of the grain, DTp, and to evaporative cooling, which accompanies the removal of water.

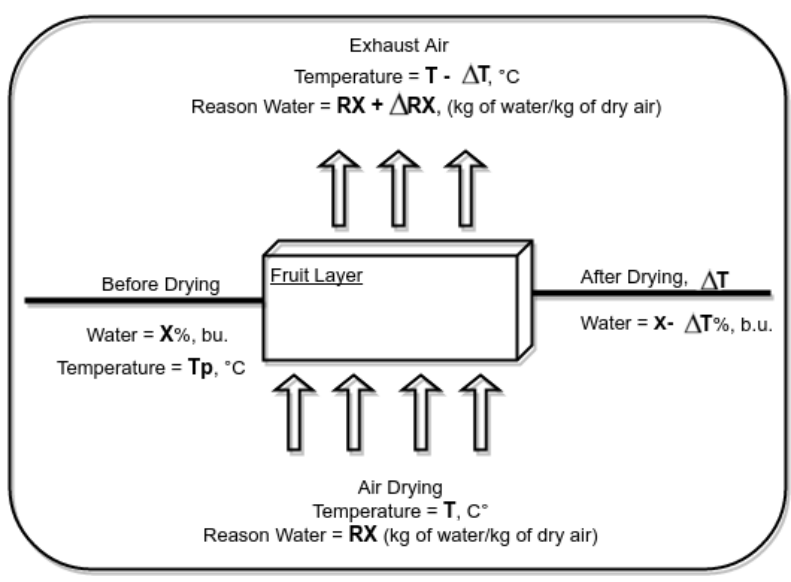

Fig 1: Scheme of drying of fruits. Translated and adapted from [16]

The computational implementation of Thomson model [12] follows the algorithm presented by Queiroz et al. (1982) [13], adding the open parameterization of equations shown below:

Reason for Conversion

$$
r c=\frac{R_{1} * \mathrm{~L} * V_{e s p}}{G_{a r} * \mathrm{dt} * C_{m} * 60}
$$

$\mathrm{R}_{1}=$ Specific mass of the fruit;

$\mathrm{L}=$ Layer Height;

$\mathrm{V}_{\text {esp }}=$ Specific Volume of the air;

$\mathrm{G}_{\mathrm{ar}}=$ Drying air flow $\mathrm{m}^{3 *} \mathrm{~m}^{-1} * \mathrm{~m}^{-2}$; 
$\mathrm{C}_{\mathrm{m}}=$ Number of Layers;

$\mathrm{dt}=$ Time interval $(\mathrm{h})$

Specific Heat

$$
C_{p}=C_{p 1}+C_{p 2} * X
$$

$\mathrm{C}_{\mathrm{p} 1}$ and $\mathrm{C}_{\mathrm{p} 2}=$ coefficients in open that rely on the fruit;

$\mathrm{X}=$ water content, base damp, decimal;

Latent heat of Vaporization

$h_{f g}=\left(h_{f g 1}-h_{f g 2}+\mathrm{T}\right) h_{f g 3} *\left(h_{f g 4} * X\right)$

$\mathrm{h}_{\mathrm{fg} 1}, \mathrm{~h}_{\mathrm{fg} 2,}, \mathrm{~h}_{\mathrm{fg} 3} \mathrm{e}_{\mathrm{fg} 4}=$ coefficients in open that rely on the fruit;

$\mathrm{X}=$ water content, base damp, decimal;

$\mathrm{T}=$ temperature $\left({ }^{\circ} \mathrm{C}\right)$;

Moisture Equilibrium (Equation of water content - Thompson)

$$
X_{e}=X_{e 1}\left(\frac{-\ln (1+U R)}{T+X_{e 2}}\right) X_{e 3}
$$

$\mathrm{X}_{\mathrm{e} 1}, \mathrm{X}_{\mathrm{e} 2}, \mathrm{X}_{\mathrm{e} 3}=$ coefficients in open that rely on the fruit;

$U R=$ relative humidity of the air \%;

Thin Layer

$$
t_{e q}=A * R X+B *(R X)^{2}
$$

$\mathrm{t}_{\mathrm{eq}}=$ equivalent time $(\mathrm{h})$;

$\mathrm{RX}=$ reason of water content;

A and B are obtained from expressions polynomial temperature-dependent and/or the water content initial of the fruit, according to expressions below.

1. Polynomial (Dependent Temperature)

$A=A_{1}+A_{2} T+A_{3} T^{2}+A_{4} T^{3}+A_{5} T^{4}+A_{6} T^{5}+A_{7} T^{6}+$

$B=B_{1}+B_{2} T+B_{3} T^{2}+B_{4} T^{3}+B_{5} T^{4}+B_{6} T^{5}+B_{7} T^{6}+$ $B_{8} T^{7}$

2. Exponential (Dependent Temperature)

$$
\begin{aligned}
& A=A_{1}+E_{x p}\left(-A_{2} T\right) \\
& B=B_{1}+E_{x p}\left(-B_{2} T\right)
\end{aligned}
$$

In the development of the model, the following assumption was adopted: the temperature of fruit is equal to temperature of the air that involves it after energy balances.

In addition to calculations made from parameterization in the open, were executed the following steps: calculation of moisture content at time intervals (increments), calculation of moisture content from Thompson equation and calculation of drying time of fruit by means of equations of the thin layer as Thompson and Page, as described below.

Equations for the Determination of Thin Layer

$t_{e q}=A * R X+B *(R X)^{2}+\Delta t$

(Thompson)

$T_{e q}=\left[\frac{-\ln (R X)}{A}\right] \frac{1}{B}$

In which $A$ and $B$ are obtained as expressions (6) e (7) ou (8) e (9).

\subsection{Software Simulator}

The computational program was developed in Java language using software platform multimedia JavaFX.

To allow a high degree of portability by adopting the techniques of developing modern, the application/simulator, was developed in the paradigm of Object-Orientation, with the interface for the user GUI intuitive and flexible, given information such as temperature, humidity, and information from the fruit.

The SecFruits has an as integrated development environment (IDE, Integrated Development Environment) the Netbeans in your version 8.0.1 based on the MVC project standard (Model-View-Controller) and Hibernate (for object-relational mapping). There was also use of technology Maven who works as a tool for management and automation of projects in Java, assisting mainly in the implementation of dependencies and in the generation of reports and documentation. To support the database was used the MySQL Database Management System.

\section{RESULTS AND DISCUSSION}

The program called SecFruits enables a high degree of interaction with the user through dialogs for inputs and outputs of data, this due to the fact of owning an easy operability and accessibility.

What differs from the SecFruits of other simulation software is the fact of making use of a database, which allows you to preserve information or data that can be analyzed whenever necessary.

Figures 2 and 3 show part of system interface, intended for insertion of each specific data and test conducted, which are stored and from these are made the calculations related to model previously determined.

The flap "Fruit" (Figure 2) allows the inclusion of new fruits, as insertion of coefficients that will be used in equations, such as: Reason for Conversion, Specific Heat, Vaporization Latent Heat of the Water and of the Fruit, Equation of Equilibrium Water Content, Fine Layer Equation and its coefficients.

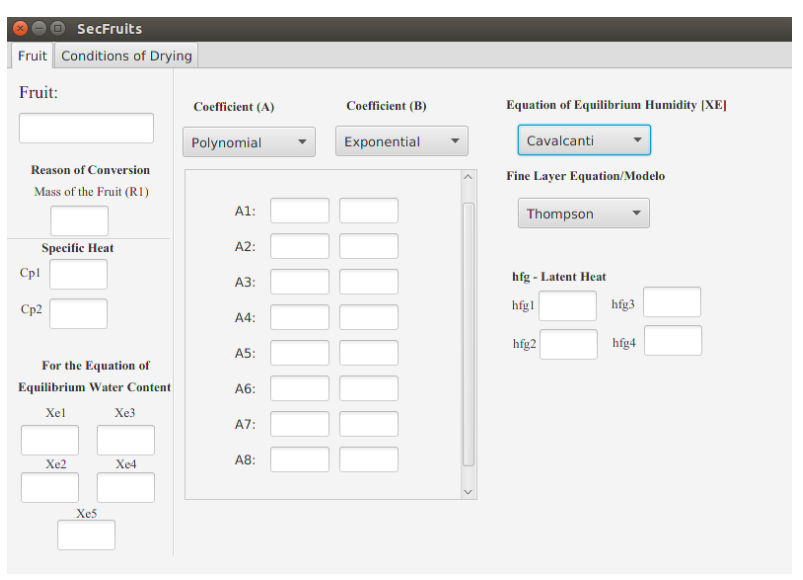

Fig 2: Secfruit - Fruit and its coefficients

The flap "Conditions of Drying" (Figure 3) will be informed as to drying conditions to be simulated by software. Once the data required for drying simulation are provided, the program performs the necessary calculations and displays a window with results, which can be presented in the form of data and/or graphs. 


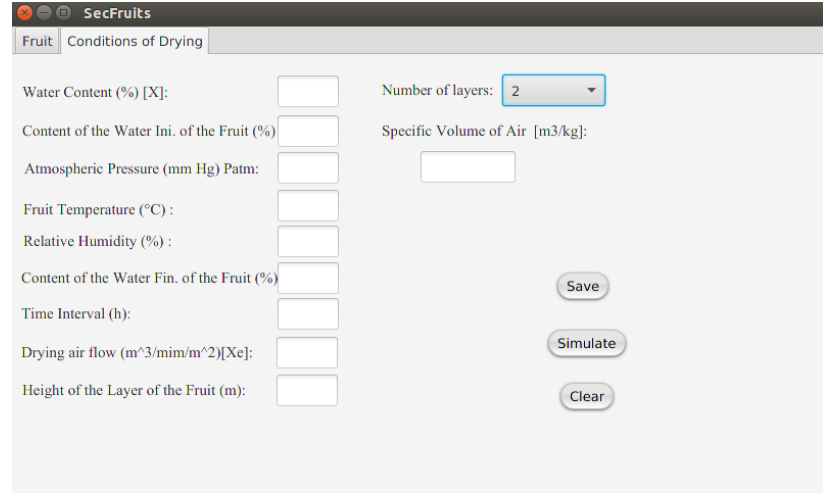

Fig 3: Data for dry condition of fruits

One of the tools that differentiate this software is the use of a database. Which makes it possible to relate, select, save, and reuse data. Figure 4 present the structure of the bank, which three different tables: tblFruit, tblCondition, tblSimulation.

The tblFruit consists in the identification of fruit, coefficients, and models to be used by Simulator. The tblCondition deals with the identification of drying conditions and relates to table tblFruit. Already the tblSimulation presents the identification of simulated data incorporated into the base.

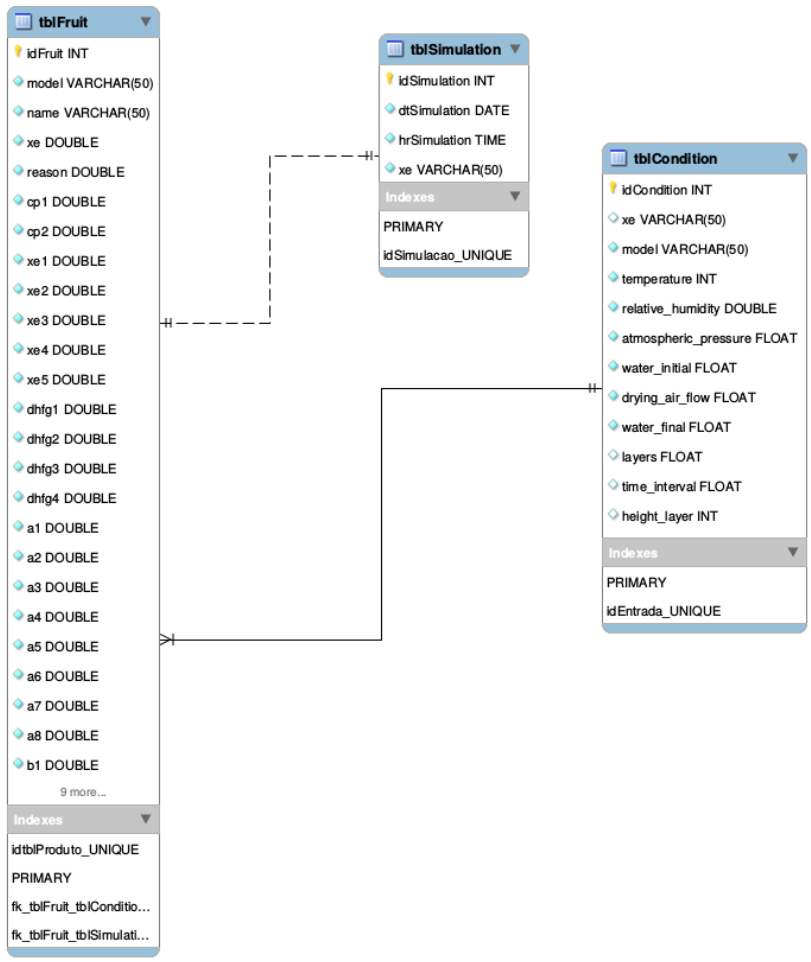

Fig 4: Structure of the database used

The parameterization used to obtain the simulated data for cashew fruit as a case study, are shown in Table 1. Some parameters required for the equation of thin layer (mass, $C_{p 1}$, $\mathrm{C}_{\mathrm{p} 2}, \mathrm{~h}_{\mathrm{fg} 1}, \mathrm{~h}_{\mathrm{fg} 2}, \mathrm{~h}_{\mathrm{fg} 3}, \mathrm{~h}_{\mathrm{fg} 4}$ ) used as an example were determined experimentally by Cavalcanti (1993) [15], in the temperature range of $40{ }^{\circ} \mathrm{C}$. The other parameters used are those available in different literatures, Dantas (2007) and Marcinkowski (2006) $[14,1]$.
Table 1. Set of parameters used in the simulation of the Cashew as case study

\begin{tabular}{|c|c|c|}
\hline Equation & $\begin{array}{l}\text { Identificatio } \\
n \text { of equation }\end{array}$ & Parameters \\
\hline $\begin{array}{l}\text { Reason for } \\
\text { conversion }\end{array}$ & Equation (1) & $\begin{array}{c}\text { Massa do Fruto (R1) } \\
=60\end{array}$ \\
\hline Specific heat & Equation (2) & $\begin{array}{c}\mathrm{C}_{\mathrm{p} 1}=0.35 ; \mathrm{C}_{\mathrm{p} 2}= \\
0.851\end{array}$ \\
\hline $\begin{array}{l}\text { Latent Heat of } \\
\text { Vaporization of } \\
\text { the Water of the } \\
\text { Fruit }\end{array}$ & Equation (3) & $\begin{array}{c}\mathrm{h}_{\mathrm{fg} 1}=6 ; \mathrm{h}_{\mathrm{fg} 2}=0.57 \\
\mathrm{~h}_{\mathrm{fg} 3}=4.35 ;[\ldots]\end{array}$ \\
\hline $\begin{array}{c}\text { Water content of } \\
\text { balance }\end{array}$ & Equation (4) & $\begin{array}{c}\mathrm{X}_{\mathrm{e} 1}=120.6 ; \mathrm{X}_{\mathrm{e} 2}= \\
45.6 ; \mathrm{X}_{\mathrm{e} 3}=0.5\end{array}$ \\
\hline Parameter A & Equation (6) & $\begin{array}{c}\mathrm{A}_{1}=13.662 ; \\
\mathrm{A}_{2}=1,1768 \\
\mathrm{~A}_{3}=0.189 ;[\ldots]\end{array}$ \\
\hline Parameter B & Equation (7) & $\begin{array}{c}\mathrm{B}_{1}=20,529 ; \mathrm{B}_{2}=- \\
0,04363 ;[\ldots]\end{array}$ \\
\hline $\begin{array}{l}\text { Equation of layer } \\
\text { Moisture Content }\end{array}$ & Equation (5) & , \\
\hline $\begin{array}{c}\text { Drying } \\
\text { temperature }\end{array}$ & - & $40^{\circ} \mathrm{C}$ \\
\hline Fruit temperature & - & $20^{\circ} \mathrm{C}$ \\
\hline Drying air flow & - & $12.2 \mathrm{~m} / 3 / \mathrm{min} / \mathrm{m}^{2}$ \\
\hline $\begin{array}{l}\text { Atmospheric } \\
\text { pressure }\end{array}$ & - & $720 \mathrm{~mm}(\mathrm{Hg})$ \\
\hline $\begin{array}{l}\text { Specific Volume } \\
\text { of Air }\end{array}$ & - & $0.907 \mathrm{~m}^{3} / \mathrm{K} \mathrm{g}$ \\
\hline Time interval & - & $1 \mathrm{~h}$ \\
\hline Water content & - & 0.13 \\
\hline
\end{tabular}

Tables 2 and 3 present the results of simulation of as a case study proposal. It is possible to observe that the table of results shown in the output of proposed software indicates that, for the simulated product to dry up to $13 \%$ moisture would require 14 hours of drying.

Table 2. Relation between time and moisture content in case study

\begin{tabular}{|c|c|}
\hline $\mathbf{t}(\mathbf{h})$ & $\mathbf{t}_{\text {eq }}(\mathbf{U})-$ Moisture content $(\%)$ \\
\hline 1 & 100 \\
\hline 2 & 69.419 \\
\hline 3 & 56.105 \\
\hline 4 & 46.945 \\
\hline 5 & 40.048 \\
\hline 6 & 34.611 \\
\hline 7 & 30.200 \\
\hline 8 & 26.549 \\
\hline 9 & 23.482 \\
\hline 10 & 20.875 \\
\hline 11 & 18.638 \\
\hline 12 & 16.704 \\
\hline
\end{tabular}




\begin{tabular}{|l|l|}
\hline 13 & 15.019 \\
\hline 14 & 13.545 \\
\hline 15 & 12.248 \\
\hline
\end{tabular}

Table 3. Simulation Results in case study

\begin{tabular}{|c|c|}
\hline \multicolumn{2}{|c|}{ SIMULATION } \\
\hline Coefficient A & 13.662 \\
\hline Coefficient B & 0.065 \\
\hline Reason for Conversion & 2497.967 \\
\hline $\begin{array}{c}\text { Latent Heat of Vaporization } \\
\text { of the Water of the Fruit }\end{array}$ & $455.345 \mathrm{kcal} . \mathrm{kg}-^{1}{ }^{\circ}{ }^{\circ} \mathrm{C}-{ }^{1}$ \\
\hline Humidity Equilibrium & $7.033 \%$ \\
\hline Specific Heat & $0.156 \mathrm{~J} . \mathrm{kg}^{-1} \cdot \mathrm{K}^{-1}$ \\
\hline Reason of water content & $0.98623 \mathrm{~kJ} \cdot \mathrm{kg}^{1}{ }^{1}$ \\
\hline
\end{tabular}

Figure 5 displays the graph generated by software to demonstrate the behavior of the moisture content during the drying time. The general behavior of a solid subjected to drying, under conditions of temperature and relative humidity fixed, tends to follow a pattern Oliveira (2006) [17]. Figure 5 represents the different stages of drying which were obtained over time.

At the beginning of the process, the temperature of fruit in contact with heating air readily tends to adjust. The steady state is reached by changing both temperatures of fruit and drying rate.

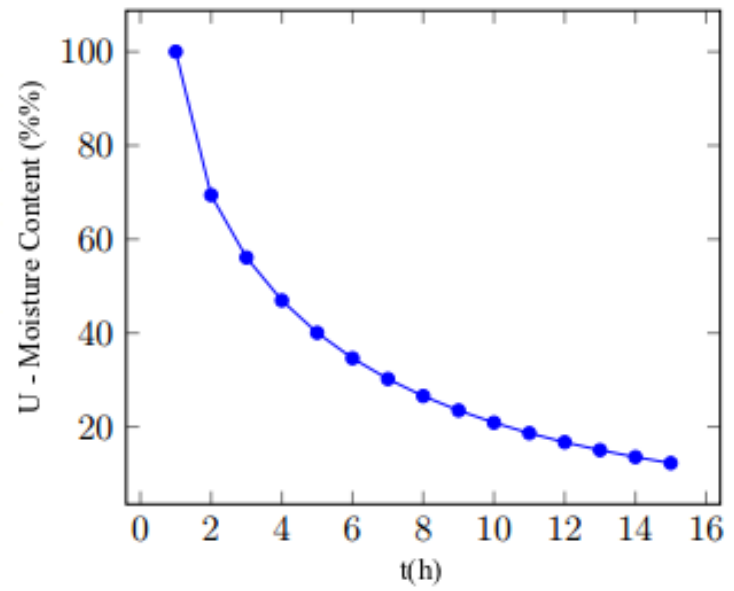

Fig 5: Graphical response presented by the software

The SecFruits was developed based on a computational tool created by Bailly (2014) [16] in his master's thesis in the course of Production Engineering. Bailly developed a software to simulate grain drying, which also makes use of some mathematical, empirical and semi-empirical models of drying, for instance, model Brooker, Lewis and Thompson.
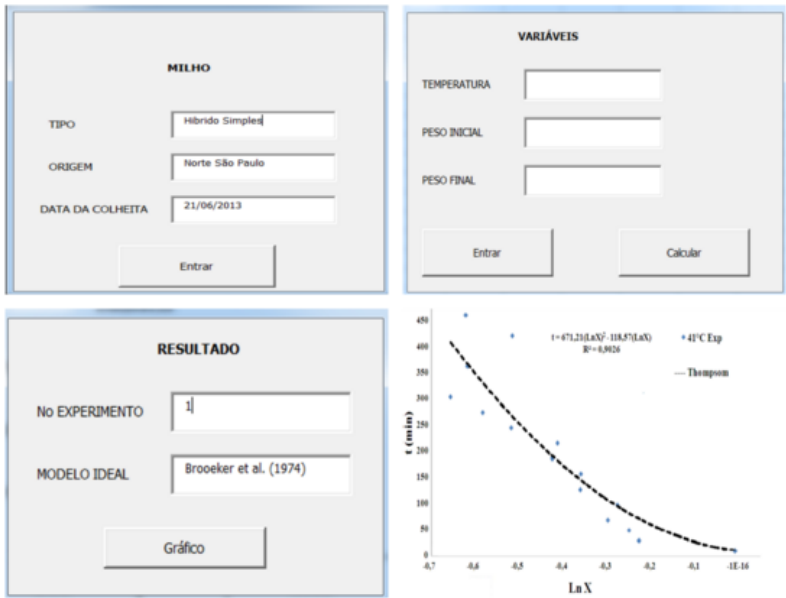

Fig 6: Graphical response presented by the software [17].

In Figure 6 has the images of the graphical interface of this software, as well as the graphical representation of a simulation of drying corn made through the software, which represents very well the curves of drying of the product simulated.

What differentiates SecFruit from other simulators is the fact that it has a database management system, which allows reusing data, as well as, through its open parameterization, it is possible to calculate some equations such as conversion reason, specific heat, among others. One can also consider its easy operability, this having a dynamic and intuitive interface.

\section{CONCLUSION}

The proposed software allows for a quick familiarization with the mechanisms involved in cerrado fruits drying, as well as allows to predict the effects of variations in operating conditions on characteristics of final the product.

\section{ACKNOWLEDGMENTS}

We would like to thank $\mathrm{CNPq}$ for the financial support.

\section{REFERENCES}

[1] MARCINKOWSKI, A. E.: Study of drying kinetics, sorption curves and prediction of thermodynamic properties of textured soybean protein. (Dissertation presented to Chemistry Engineering program of Federal University of Rio Grande do Sul) 2006.

[2] THOMPSON, T. L.; PEART, R. M.; FOSTER, G. H. Mathematical simulation of corn drying - A new model. Transaction of the ASAE, Saint Joseph, Michigan, v. 11, n. 4, p. 582- 586, 1968.

[3] GOL, N.B.; CHAUDHARI, M.L.; RAO, T.V.R. Effect of edible coatings on quality and shelf life of carambola (Averrhoa carambola L.) fruit during storage. Journal of Food Science and Technology. v.52. issue 1. pp.78-91. 2015.

[4] QUEIROZ, D.M.; SILVA, J.S.; MELO, E.C. Drying simulation practice on programmable calculators. Viçosa, Centro Nacional de Treinamento em Armazenagem, 1982 84p.

[5] OLIVEIRA, R. J.: Development of a Thin-Grain Fine Drying System: Coparization Among Simulation Mathematical Models for Bean-Macácar Grains. (Dissertation presented to Federal University of Campina Grande) 2006. 
[6] SIUCINSKA, K. KONOPACKA, D.; MIESZCZAKOWSKA-FRAC, M.; POLUBOK, A. The effects of ultrasound on quality and nutritional aspects of dried sour cherries during shelf-life. LWT-Food Science and Technology. v.68. pp. 168-173. 2016.

[7] JUNIOR, L.C.C; NARDINI, V.; KHATIWADA, B.P.; TEIXIERA, G.H.A.; WALSH, K.B. Classification of intact açaí (Euterpe pleracea Mart.) and juçara (Euterpe edulis Mart) fruits based on dry matter contente by means of near infrared spectroscopu. Food Control. v.50. pp.630-636. 2015.

[8] BEJAUOI, M.A.; BELTRAN, G.; AGUILERA, M.P.; JIMENEZ, A. Continuous conditioning of olive paste by high power ultrasounds: response surfasse methodology to predict temperature and its effect on oil yield and virgin olive oil characteristics. LWT - Food Science and Technology. v.69, pp.175-184. 2016.

[9] CHAUHAN, P.S.; KUMAR, A.; TEKASAKUL, P. Applications of software in solar drying systems: A review. Renewable and Sustainable Energy Reviews. v.51., pp1326-1337. 2015.

[10] BAILLY, R.:Desenvolvimento de um Protótipo de Secador Infravermelho e de uma Ferramenta Computacional Para Auxiliar as Empresas de Beneficiamento de Grãos na Obtenção de Curvas de Secagem. Julho de 2014. 86. Dissertação de Mestrado Universidade Nove de Julho. São Paulo.

[11] RUNGPICHAYAPICHET, P.; MAHAYOTHEE, B.; NAGLE, M.; KHUWIJITJARU, P.; MULLER, J. Robust NIRS models for non-destructive prediction of postharvest fruit ripeness and quality in mango.
Postharvest Biology and Technology. v.111, pp.31-40. 2015.

[12] NARCISO, P. J. Valorization of cerrado fruits: Development of pequi powder seasoning. (Dissertation presented to Federal University of Grande Dourados) 2012.

[13] COLTRI, P.P.; JUNIOR, J.Z.; DUBREUIL, V.; RAMIREZ, G.M.; PINTO, H.S.; CORAL， G.; LAZARIM, C.G. Empiracal models to predict LAI and aboverground biomass of coffea arábica under full sun and shaded plantation: a case study of south of Minas Gerais, Brasil. Agroforestry Systems. v.89, issue 4, pp.621-636. 2015.

[14] DANTAS, L. A.: Development of a Dynamic Computational Program for Simulation of Drying of Grains and Seeds. (Dissertation presented to Agricultural Engineering program of Federal University of Campina Grande). 2007.

[15] RUBIO-CELORIO, M.; GARCIA-GIL, N.; GOU, P.; ARNAU, J.; FULLADOSA, E. Effect of temperature, high pressure and freezing/thawing of dry-cured ham slices on dielectric time domain reflectometry response. Meat Science. v.100. pp.91-96. 2015

[16] CAVALCANTI MATA, M.E.R.M. Simulation of BR451 white maize drying in stationary layer dryer. (Thesis presented to Federal University of Paraiba). 140 p. 1993.

[17] MATA, C.; Dantas, A.; BRAGA, M; Computer Program For Grain Drying Simulation. Revista Brasileira de Produtos Agroindustriais, Campina Grande, v.1, n.1, p.33-50, 1999. 